Cobalt Phosphide Nanorods as an Efficient Electrocatalyst for Hydrogen Evolution Reaction

Zhipeng Huang, Zhongzhong Chen, Zhibo Chen, Cuncai Lv, Mark G. Humphrey, Chi Zhang

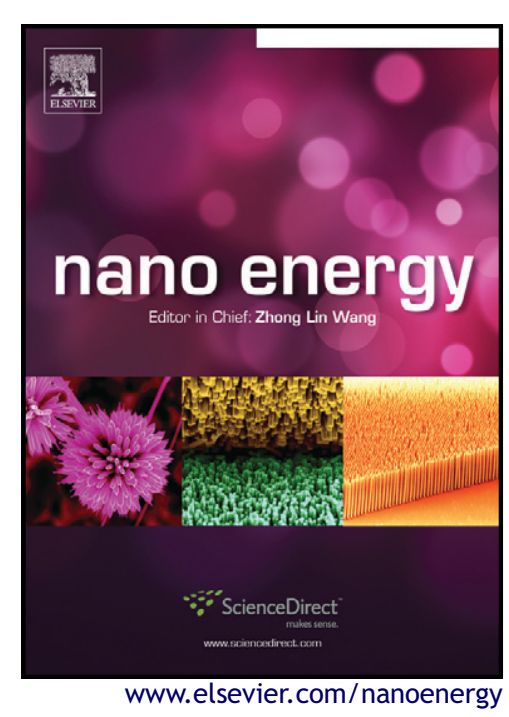

PII: S2211-2855(14)00179-7

DOI: http://dx.doi.org/10.1016/j.nanoen.2014.08.013

Reference: NANOEN466

To appear in: Nano Energy

Received date: 13 June 2014 Revised date: 11 August 2014 Accepted date: 18 August 2014

Cite this article as: Zhipeng Huang, Zhongzhong Chen, Zhibo Chen, Cuncai Lv, Mark G. Humphrey, Chi Zhang, Cobalt Phosphide Nanorods as an Efficient Electrocatalyst for Hydrogen Evolution Reaction, Nano Energy, http://dx.doi.org/ 10.1016/j.nanoen.2014.08.013

This is a PDF file of an unedited manuscript that has been accepted for publication. As a service to our customers we are providing this early version of the manuscript. The manuscript will undergo copyediting, typesetting, and review of the resulting galley proof before it is published in its final citable form. Please note that during the production process errors may be discovered which could affect the content, and all legal disclaimers that apply to the journal pertain. 


\title{
Cobalt Phosphide Nanorods as an Efficient Electrocatalyst for Hydrogen Evolution Reaction
}

Zhipeng Huang, ${ }^{* a}$ Zhongzhong Chen, ${ }^{a}$ Zhibo Chen, ${ }^{a}$ Cuncai Lv, ${ }^{a}$ Mark G. Humphrey, ${ }^{b}$ and Chi Zhang*a

${ }^{a}$ China-Australia Joint Research Center for Functional Molecular Materials, Scientific Research Academy, Jiangsu University, Zhenjiang, Jiangsu, P.R. China (212013). Fax/Tel: 86-511-88797815

${ }^{b}$ Research School of Chemistry, Australian National University, Canberra, ACT 0200, Australia

*Corresponding author. Zhipeng Huang, Chi Zhang

E-mail: zphuang@ujs.edu.cn, chizhang@ujs.edu.cn; Phone/Fax:+86-511-88797815

\begin{abstract}
Cobalt phosphide $\left(\mathrm{Co}_{2} \mathrm{P}\right)$ nanorods are found to exhibit efficient catalytic activity in hydrogen evolution reaction (HER), with the overpotential required for the current density of 20 $\mathrm{mA} / \mathrm{cm}^{2}$ as small as $167 \mathrm{mV}$ in acidic solution and $171 \mathrm{mV}$ in basic solution. In addition, the $\mathrm{Co}_{2} \mathrm{P}$ nanorods can work stably in both acidic and basic solution during hydrogen production. This performance can be favorably comparable to typical high efficiently non-precious catalysts, and suggest the promising application potential of the $\mathrm{Co}_{2} \mathrm{P}$ nanorods in the field of hydrogen production. The HER process follows a Volmer-Heyrovsky mechanism, and the rates of the discharge step and desorption step appear to be comparable during the HER process. The similarity of charged natures of $\mathrm{Co}$ and $\mathrm{P}$ in the $\mathrm{Co}_{2} \mathrm{P}$ nanorods to those of the hydride-acceptor and proton-acceptor in high efficient $\mathrm{Ni}_{2} \mathrm{P}$ catalyst, $[\mathrm{NiFe}]$ hydrogenase, and its analogues implies that the HER catalytic activity of $\mathrm{Co}_{2} \mathrm{P}$ nanorods might be correlated with the charged natures of Co and P.
\end{abstract}

\section{Keywords}

cobalt phosphide; nanorod; electrocatalyst; hydrogen generation 


\section{Introduction}

The solar-driven splitting of water into molecular hydrogen and oxygen is one of the most promising possibilities for simultaneously solving the global energy crisis and current environmental issues.[1-3] Because of the intrinsically slow hydrogen evolution reaction (HER) kinetics of semiconductors, photocathodes must be decorated with HER catalysts for efficient hydrogen production. Though platinum remains the most effective HER catalyst, having been shown to significantly enhance the hydrogen production capability of photocathodes several decades ago, $[4,5]$ it is a limited resource and expensive, and so its widespread practical application in the field of solar-driven hydrogen production may be limited. There is therefore a demonstrable need for non-precious HER catalysts.

Recently, a variety of new HER catalysts have been reported, including molybdenum sulfide, [6, 7] molybdenum carbide,[8-10] molybdenum nitride,[10] molybdenum boride,[8] tungsten carbide,[11, 12] tungsten carbonitride,[13] first-row transition-metal dichalcogenides,[14, 15] nickel selenide,[16] nickel phosphide,[17] cobalt phosphide (CoP), [18-20] molybdenum phosphide,[21, 22] and etc. The first-row transition-metal dichalcogenides have similar coordination structure as the active centers in efficient hydrogenase,[15] and the charged natures of metal and $\mathrm{P}$ in metal phosphides are similar to those of the hydride-acceptor and proton-acceptor in $[\mathrm{NiFe}]$ hydrogenase and its analogues $\left([\mathrm{Ni}(\mathrm{PS} 3 *)(\mathrm{CO})]^{1-}\right.$ and $\left.\left[\mathrm{Ni}(\mathrm{PNP})_{2}\right]^{2+}\right) \cdot[23]$

Here the HER performance of cobalt phosphide $\left(\mathrm{Co}_{2} \mathrm{P}\right)$ nanorods is introduced. Although their structure and composition are different from all heretofore reported HER catalysts, the $\mathrm{Co}_{2} \mathrm{P}$ nanorods 
exhibit efficient and stable HER catalytic activity in both acidic and basic solutions. The overpotential required for a current density of $20 \mathrm{~mA} / \mathrm{cm}^{2}\left(\eta_{20}\right)$ is as small as $167 \mathrm{mV}$ in acidic solution and $171 \mathrm{mV}$ in basic solution. The $\eta_{20}$ of the $\mathrm{Co}_{2} \mathrm{P}$ nanorods lies in the top 10 of the reported values of non-precious HER catalysts. It is worth noting that the four reported $\eta_{20}$ better than that of the $\mathrm{Co}_{2} \mathrm{P}$ nanorods were obtained from the composites of catalysts and nanostructured conductive supports, including $\mathrm{Mo}_{1} \mathrm{So}_{\mathrm{y}}$ particles loaded on reduced graphene oxide $\left(\mathrm{Mo}_{1} \mathrm{So}_{\mathrm{y}} / \mathrm{rGO}\right),[10] \mathrm{CoP}$ nanoparticles loading on carbon nanotube (CoP/CNT),[18] CoP nanowires loaded on carbon cloth (CoP/CC),[20] and $\mathrm{MoS}_{2}$ loaded on mesoporous graphene foam ( $\left.\mathrm{MoS}_{2} / \mathrm{MGF}\right)$.[24] The nanostructured conductive supports have been well known to improve the electron transport among catalysts and therefore the performance of catalyst.[25] The charged natures of $\mathrm{Co}$ and $\mathrm{P}$ in the $\mathrm{Co}_{2} \mathrm{P}$ nanorods are similar to those of the hydride-acceptor and proton-acceptor in $\mathrm{Ni}_{2} \mathrm{P}$ catalyst, $[\mathrm{NiFe}]$ hydrogenase, and its analogues. Such similarity might afford the efficient catalytic activity of the $\mathrm{Co}_{2} \mathrm{P}$ nanorods.

\section{Materials and methods}

2.1 Synthesis of $\mathrm{Co}_{2} \mathbf{P}$ nanorods. Cobalt acetate tetrahydrate $(0.50 \mathrm{~g}, 2 \mathrm{mmol})$ was mixed with oleylamine (12 g, $45 \mathrm{mmol})$ in a $100 \mathrm{~mL}$ round-bottom flask. The flask was heated via a heating mantle. Dispersion was obtained by stirring the mixture at $70{ }^{\circ} \mathrm{C}$. The dispersion was then heated to $120{ }^{\circ} \mathrm{C}$ and triphenylphosphine $(5.246 \mathrm{~g}, 20 \mathrm{mmol})$ was added to the mixture. The flask was pumped under vacuum at $120^{\circ} \mathrm{C}$ for 30 min to remove water, and then refilled with $\mathrm{N}_{2}$. The temperature of the 
heating mantle was increased to $370{ }^{\circ} \mathrm{C}$ and maintained at this value for $10 \mathrm{~min}$. The flask was removed from the heating mantle and cooled to room temperature. The black product was isolated and washed by repeated centrifugation/ultrasonication, with hexane as good solvent and ethanol as nonsolvent. Finally, the product was dried under vacuum at room temperature.

2.2 Characterization. The morphology of $\mathrm{Co}_{2} \mathrm{P}$ nanorods was assessed by transmission electron microscopy (TEM, 200 kV, JEM2100, JEOL) and scanning electron microscopy (SEM, 7001F, JEOL). The energy-dispersive X-ray spectroscopy (EDX) spectrum was recorded using a GENESIS 2000 XM 30T (EDXA) on a JEM2100. For the TEM investigation, the $\mathrm{Co}_{2} \mathrm{P}$ nanorods were dispersed in hexane by ultrasonication. The dispersion was dropped onto a carbon-coated copper grid (300-mesh). The copper grid was then dried at $100{ }^{\circ} \mathrm{C}$ for 5 min before the TEM characterization. Powder X-ray diffraction (XRD) patterns were collected using a D8 Advance diffractometer with graphitemonochromated $\mathrm{Cu} \mathrm{K} \alpha$ radiation $(\lambda=1.54178 \AA)$. The X-ray photoelectron spectroscopy (XPS) experiments were carried out on an ESCALAB250Xi System (ThermoFisher) equipped with a monochromatic $\mathrm{Al} \mathrm{K \alpha}(1486.6 \mathrm{eV})$ source and a concentric hemispherical energy analyzer. The binding energy $\mathrm{C}$ 1s peak from surface adventitious carbon $(284.8 \mathrm{eV})$ was adopted as a reference for the binding energy measurements.

2.3 Electrochemical performance. $\mathrm{Co}_{2} \mathrm{P}$ nanorods $(15 \mathrm{mg})$ were dispersed in hexane $(0.5 \mathrm{~mL})$ with the aid of an ultrasonic horn $(2 \mathrm{~mm}$ diameter, $130 \mathrm{~W}, 60 \mathrm{~min})$. The dispersion $(17 \mu \mathrm{L})$ was dropped onto a clean Ti foil $\left(0.5 \mathrm{~cm}^{2}\right)$ and dried naturally. The Ti foil was polished by sandpaper (7000 mesh), 4 
and then cleaned by acetone, ethanol, de-ionized water (15 min each) prior to the drop-coating of the $\mathrm{Co}_{2} \mathrm{P}$ nanorods. The $\mathrm{Co}_{2} \mathrm{P}$ nanorods loaded on the Ti foil were annealed in $5 \% \mathrm{H}_{2} / \mathrm{N}_{2}$ at $450{ }^{\circ} \mathrm{C}$ for 30 min to remove surface ligands.

All electrochemical measurements were carried out with an electrochemical workstation (CHI 614D, $\mathrm{CH}$ Instrument) in a three-electrode configuration, with $\mathrm{Co}_{2} \mathrm{P}$ (loaded onto Ti foil) as a working electrode, a graphite rod (6 mm diameter) as a counter electrode, and a mercury/mercurous sulfate electrode (MSE) or mercury/mercury oxide electrode (MMO) as a reference electrode. The samples were assembled into a homemade electrochemical cell, with only a defined area $\left(\sim 0.07 \mathrm{~cm}^{2}\right)$ of the front surface of the sample exposed to solution during the measurements. The counter electrode was separated from working chamber by porous glass frit.

$\mathrm{H}_{2} \mathrm{SO}_{4}$ aqueous solution $(0.5 \mathrm{M})$ or $\mathrm{KOH}$ aqueous solution $(1 \mathrm{M})$ was used for electrochemical measurements. The MSE is used as the reference electrode in $\mathrm{H}_{2} \mathrm{SO}_{4}$ solution, and the MMO is used in $\mathrm{KOH}$ solution. The solutions were purged with high purity $\mathrm{H}_{2}(99.999 \%)$ for 30 min prior to electrochemical measurements. The reversible hydrogen evolution potential (RHE) was determined by the open circuit potential of a clean Pt electrode in the solution of interest bubbled with $\mathrm{H}_{2}(99.999 \%)$, being $-0.694 \mathrm{~V}$ vs. MSE for the $0.5 \mathrm{M} \mathrm{H}_{2} \mathrm{SO}_{4}$ solution and $-0.876 \mathrm{~V}$ vs. $\mathrm{MMO}$ for the $1 \mathrm{M} \mathrm{KOH}$ solution. A potential measured with respect to the MSE electrode was therefore referenced to the RHE by adding a value of $0.694 \mathrm{~V}$ for the measurements in the $0.5 \mathrm{M} \mathrm{H}_{2} \mathrm{SO}_{4}$ solution, and a potential measured with respect to the MMO electrode in the $\mathrm{KOH}$ solution was referenced to the RHE by 5 
adding a value of $0.876 \mathrm{~V}$.

Polarization curves of $\mathrm{Co}_{2} \mathrm{P}$ samples were measured at a sweep rate of $5 \mathrm{mV} / \mathrm{s}$ in rigorously stirred solution $(1600 \mathrm{rpm})$. The uncompensated cell resistance $(R)$ was determined by currentinterrupt method, and the experimental potential was corrected by subtracting ohmic drop $(i R)$, where $i$ is the current corresponding to the experimental potential. The apparent Tafel slope was derived from the $i R$-corrected polarization curve by fitting experimental data to the equation $\eta=a+b l o g j$, where $\eta$ is the $i R$-corrected potential, $a$ is the Tafel constant, $b$ is the Tafel slope, and $j$ is the current density. Electrochemical impedance spectroscopy (EIS) measurements were carried out at different potentials in the frequency range of $10^{-2}$ to $10^{6} \mathrm{~Hz}$ with $10 \mathrm{mV}$ sinusoidal perturbations and 12 steps per decade in $0.5 \mathrm{M} \mathrm{H}_{2} \mathrm{SO}_{4}$ solution.

For accelerated degradation investigations, cyclic voltammetric (CV) measurements were carried out with a $50 \mathrm{mV} / \mathrm{s}$ sweep rate between -0.240 and $0.100 \mathrm{~V}$ vs. RHE in the $0.5 \mathrm{M} \mathrm{H}_{2} \mathrm{SO}_{4}$ solution, and 0.330 and $0.080 \mathrm{~V}$ vs. RHE in the $1 \mathrm{M} \mathrm{KOH}$ solution, without accounting for uncompensated resistance.

The volume of $\mathrm{H}_{2}$ during the potentiostatic electrolysis experiment was monitored by volume displacement in a configuration shown in Figure S1 (Electronic Supplementary Information). In this experiment, the backside of the $\mathrm{Ti}$ foil was connected to a $\mathrm{Cu}$ wire with $\mathrm{Ag}$ paste. The $\mathrm{Cu}$ wire was threaded to a glass tube ( $6 \mathrm{~mm}$ diameter), and the backside and front side of sample electrode were then sealed with epoxy resin with the exception of an exposed area $\left(\sim 0.5 \mathrm{~cm}^{2}\right)$. A Freescale 
MPXV7002DP differential pressure transducer was employed to monitor pressure variation in the gas gathering tube, and then the volume of generated $\mathrm{H}_{2}$ was computed from pressure variation in the gas gathering tube (see details in Electronic Supplementary Information). The current and charge passing the $\mathrm{Co}_{2} \mathrm{P}$ nanorods were measured with the electrochemical workstation and the voltage change of the differential pressure transducer was monitored with a digital multimeter (4 $1 / 2$ digits). Prior to experiment, the relationship between volume of gathered gas and the variation of output voltage of the differential pressure transducer (i.e., pressure variation in the gas gathering tube) was calibrated by injecting known amounts of air into the gas gathering tube and recording the variation of output voltage of the differential pressure transducer.

\section{Results and discussion}

$\mathrm{Co}_{2} \mathrm{P}$ nanorods were synthesized using low cost precursors at $370{ }^{\circ} \mathrm{C}$. Cobalt acetate and triphenylphosphine were adopted as cobalt source and phosphorus source, respectively, and oleylamine was used as heating media and surface capping agent. The overall structural feature of the

resultant $\mathrm{Co}_{2} \mathrm{P}$ nanorods was revealed by XRD experiments (Figure 1). The observed well-defined peaks are consistent with the good crystallinity of the products, the peaks matching well those from orthorhombic phase $\mathrm{Co}_{2} \mathrm{P}$ (JCPDS No. 32-306, a = 5.6465 $\AA, \mathrm{b}=6.6099 \AA, \mathrm{c}=3.5130 \AA$ ). 


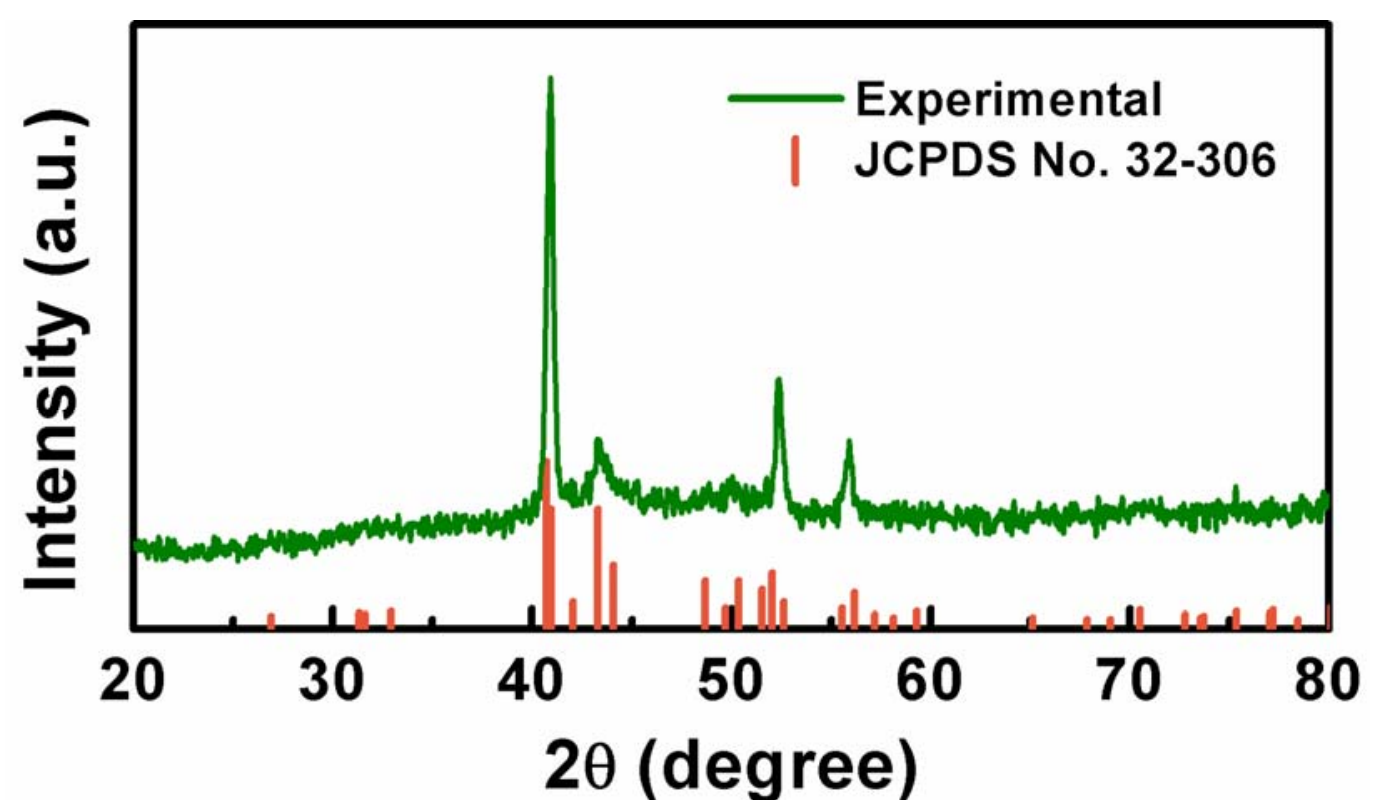

Figure 1. Experimental XRD pattern of the $\mathrm{Co}_{2} \mathrm{P}$ nanorods.

The morphology and microstructure of the $\mathrm{Co}_{2} \mathrm{P}$ nanorods were assessed via TEM. A typical TEM image can be found in Figure 2a. The product has a rod-like morphology, with $9.8 \pm 1.3 \mathrm{~nm}$ diameter and $110.0 \pm 11.8 \mathrm{~nm}$ length (Figure S2, Electronic Supplementary Information). The rod-like morphology of the $\mathrm{Co}_{2} \mathrm{P}$ was further confirmed by a SEM image (Figure S3, Electronic Supplementary Information). A high resolution TEM (HRTEM) image of the $\mathrm{Co}_{2} \mathrm{P}$ nanorods can be found in Figure $2 b$, in which lattice fringes can be clearly seen. These fringes suggest the good crystallinity of $\mathrm{Co}_{2} \mathrm{P}$, in accordance with that revealed by the XRD experiment. The fast Fourier transform (FFT) pattern of the lattice fringes shows the corresponding diffraction pattern of the $\mathrm{Co}_{2} \mathrm{P}$ nanorods (inset of Figure $2 \mathrm{~b}$ ). The pattern can be indexed to the [-210] zone-axis patterns of orthorhombic phase $\mathrm{Co}_{2} \mathrm{P}\left(1 / \mathrm{d}_{\mathrm{OA}}=\mathrm{d}_{(121)}\right.$ $\left.=2.2 \AA, 1 / \mathrm{d}_{\mathrm{OB}}=\mathrm{d}_{(002)}=1.7 \AA, 1 / \mathrm{d}_{\mathrm{OC}}=\mathrm{d}_{(-1-21)}=2.2 \AA, \angle \mathrm{AOB}=\angle \mathrm{BOC}=51^{\circ}\right)$. The FFT pattern reveals that the $\mathrm{Co}_{2} \mathrm{P}$ nanorods grew along the [002] direction. HRTEM images from other nanorods reveal the 
same growth direction. EDX spectra recorded from nanorods confirm the presence of Co and $\mathrm{P}$ in the nanorods (Figure S4, Electronic Supplementary Information).
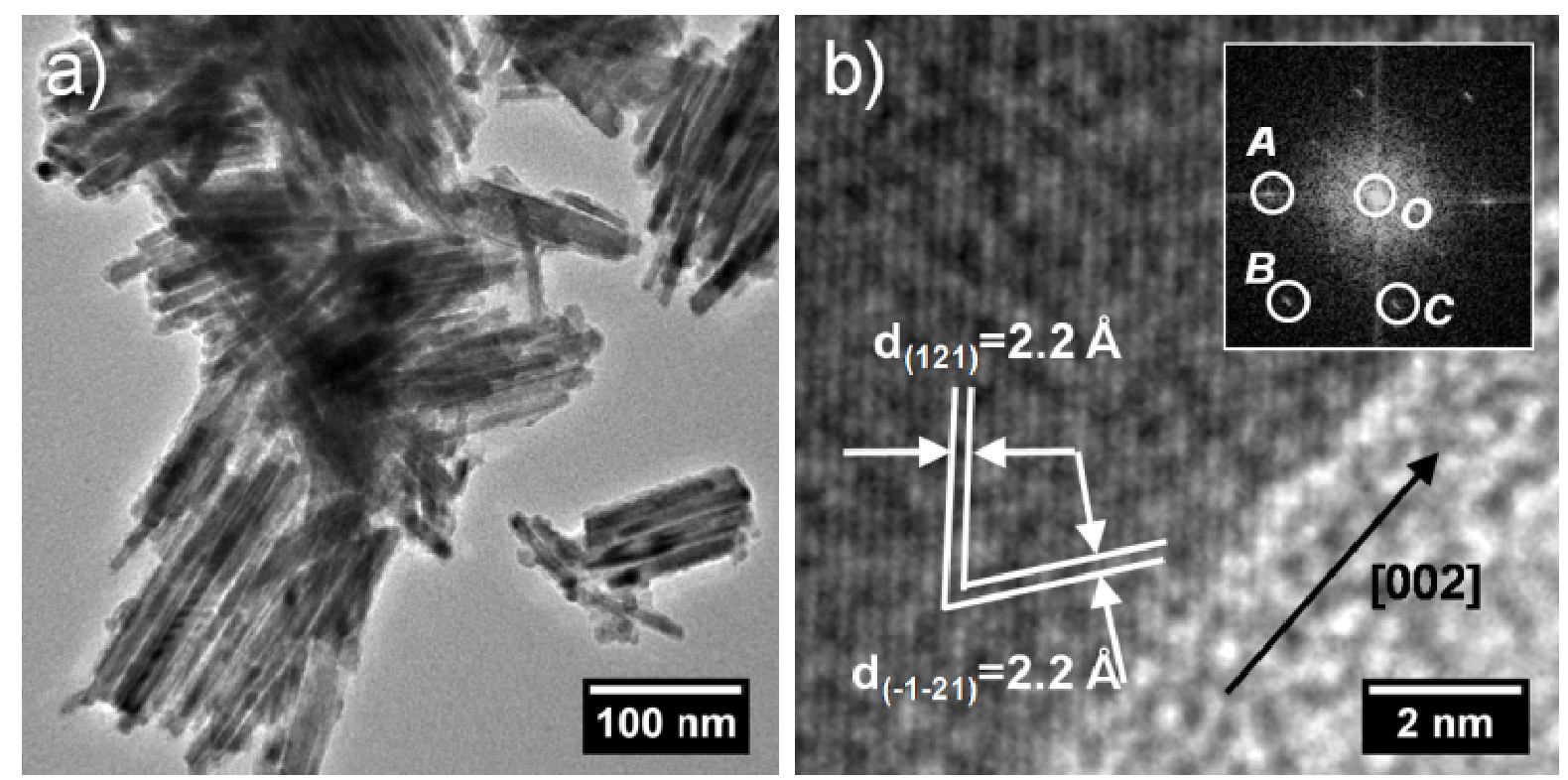

Figure 2. (a) TEM and (b) HRTEM images of the $\mathrm{Co}_{2} \mathrm{P}$ nanorods.

The chemical states of $\mathrm{Co}$ and $\mathrm{P}$ on the surface of the $\mathrm{Co}_{2} \mathrm{P}$ nanorods were revealed by XPS experiments. Figure 3 shows the XPS spectra of the Co $2 p$ window and the P $2 p$ window recorded from the $\mathrm{Co}_{2} \mathrm{P}$ nanorods subjected to annealing $\left(450{ }^{\circ} \mathrm{C}, 5 \% \mathrm{H}_{2} / \mathrm{N}_{2}, 30 \mathrm{~min}\right)$. Three distinct doublets can be clearly seen in the XPS spectrum of the Co $2 p$ window (Figure $3 a$ ), with Co $2 p_{3 / 2}$ binding energies at 778.2, 781.7 and $785.6 \mathrm{eV}$. The peak at $778.2 \mathrm{eV}$ suggests that there are reduced Co species in $\mathrm{Co}_{2} \mathrm{P}^{[36]}$ These reduced Co species are partially charged $\left(\mathrm{Co}^{\delta+}, 0<\delta<2\right)$, and $\delta$ must have a small value, because the corresponding Co $2 \mathrm{p}_{3 / 2}$ binding energy $(778.2 \mathrm{eV})$ is very close to that of metallic Co $(777.9 \mathrm{eV})$.[26] The P $2 \mathrm{p}$ window of the XPS spectrum shows two doublets with peak binding 
energies at 129.4 and $133.5 \mathrm{eV}$. The doublet at $129.4 \mathrm{eV}$ suggests the presence of partially negatively charged $\mathrm{P}\left(\mathrm{P}^{\delta-},-1<\delta<0\right)$, and the value of $\delta$ is likely to be small, because the corresponding energy $(129.4 \mathrm{eV})$ is close to that of elemental $\mathrm{P}(130.0 \mathrm{eV})$.[27] The Co $2 \mathrm{p}$ peak observed at $781.7 \mathrm{eV}$ and its satellite at $785.6 \mathrm{eV}$ can be assigned to Co oxidation state, which could be associated with cobalt phosphate formed on the surface of the $\mathrm{Co}_{2} \mathrm{P}$ nanorods.[28] The presence of cobalt phosphate on the surface of $\mathrm{Co}_{2} \mathrm{P}$ nanorods is also suggested by $\mathrm{P} 2 \mathrm{p}$ peak centered at $133.5 \mathrm{eV}$ and $\mathrm{O} 1$ s peak centered at $531.6 \mathrm{eV}$ (Figure S5, Electronic Supplementary Information), which resemble well those of $\mathrm{P}$ and O species in cobalt phosphate.[28]
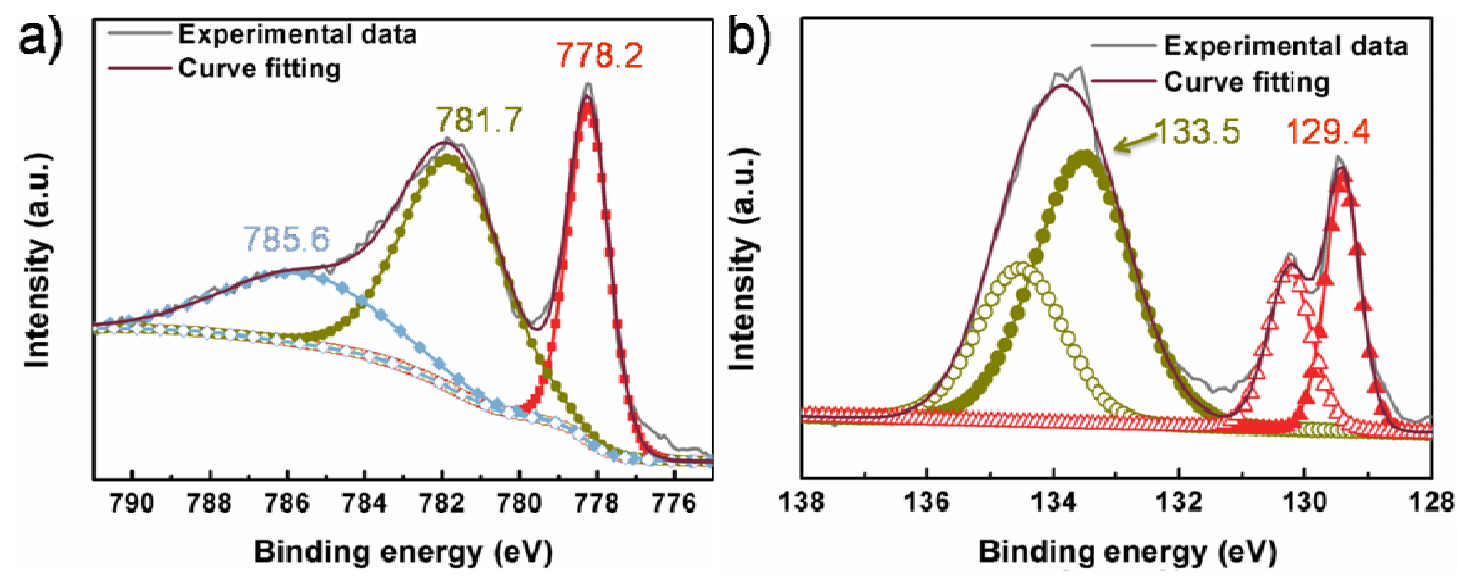

Figure 3. XPS spectra of (a) the Co $2 p_{3 / 2}$ and (b) the P $2 p$ windows.

The HER performance of the $\mathrm{Co}_{2} \mathrm{P}$ nanorods was evaluated by polarization curve measurements (j-V plots). Prior to measurements, The $\mathrm{Co}_{2} \mathrm{P}$ nanorods were applied to Ti foils (loading amount ca. 1 $\mathrm{mg} / \mathrm{cm}^{2}$ ) by drop coating, and annealed at $450{ }^{\circ} \mathrm{C}$ in a $5 \% \mathrm{H}_{2} / \mathrm{N}_{2}$ atmosphere for 30 min to remove surface ligand.[17] The measurements were carried out in a $0.5 \mathrm{M} \mathrm{H}_{2} \mathrm{SO}_{4}$ solution with a three- 
electrode configuration (see details in Materials and methods). Figure 4 a shows the $j-V$ plots of the $\mathrm{Co}_{2} \mathrm{P}$ nanorods, bare Ti foil, commercial Pt/C (Johnson Matthey, Hispec 3000, 20 wt.\%) loaded on a glassy carbon electrode (GCE), and a bare GCE. It was verified that cobalt phosphate can be dissolved in the $0.5 \mathrm{M} \mathrm{H}_{2} \mathrm{SO}_{4}$ solution (Figure S6, Electronic Supplementary Information), therefore the cobalt phosphate presented on the surface of the $\mathrm{Co}_{2} \mathrm{P}$ nanorods would be dissolved and should not affect the catalytic activity of $\mathrm{Co}_{2} \mathrm{P}$ nanorods during the electrochemistry measurements. It can be seen that the bare Ti foil exhibits negligible current flow in the potential range of -250 to $0 \mathrm{mV}$ vs. RHE, suggesting that the current flow of the $\mathrm{Co}_{2} \mathrm{P}$ nanorods supported on the Ti foil sample in this potential range is induced by the $\mathrm{Co}_{2} \mathrm{P}$ nanorods, but not the Ti foil. The onset of current is found at ca. $-70 \mathrm{mV}$ vs. RHE for the $\mathrm{Co}_{2} \mathrm{P}$ nanorods. The $\eta_{20}$ is $167 \mathrm{mV}$ for the $\mathrm{Co}_{2} \mathrm{P}$ nanorods, and the overpotential required for a current density of $10 \mathrm{~mA} / \mathrm{cm}^{2}\left(\eta_{10}\right)$ is $134 \mathrm{mV}$. The $\eta_{20}$ and $\eta_{10}$ values of different catalysts are usually compared in order to evaluate their efficiencies, because in photoelectrochemical applications a photocathode produces a current flux of $10-20 \mathrm{~mA} / \mathrm{cm}^{2}$ under 1 sun of AM $1.5 \mathrm{G}$ illumination.[3] The performance of representative HER catalysts is summarized in Table 1. It can be seen that the $\eta_{20}$ and $\eta_{10}$ values of the $\mathrm{Co}_{2} \mathrm{P}$ nanorods in our experiments are only larger than those of $\mathrm{CoP}$ nanoparticles,[19] $\mathrm{Ni}_{2} \mathrm{P}$ nanoparticles,[17] Ni-Mo nanopowders,[29] MoP nanoparticles,[21, 22] CoP/CC,[20] $\mathrm{CoP} / \mathrm{CNT},[18] \mathrm{Mo}_{1} \mathrm{Soy} / \mathrm{rGO}$ [10] and $\mathrm{MoS}_{2} / \mathrm{MGF}$ ),[24] and smaller than other listed catalysts. Ni-Mo nanopowders degrade rapidly in acidic condition, rendering their exploitation problematic.[29] The conductive $\mathrm{CC}, \mathrm{CNT}, \mathrm{rGO}, \mathrm{MGF}$ in $\mathrm{CoP} / \mathrm{CC}, \mathrm{CoP} / \mathrm{CNT}, \mathrm{Mo}_{1} \mathrm{Soy} / \mathrm{rGO}$ or $\mathrm{MoS}_{2} / \mathrm{MGF}$ enhances the 11 
HER performance of these composites, in contrast to the $\mathrm{Co}_{2} \mathrm{P}$ nanorods in our experiments which are loaded on the Ti foil. This comparison demonstrates that the HER performance of the $\mathrm{Co}_{2} \mathrm{P}$ nanorods in our experiments is favorably comparable to most values of recently reported high efficiency nonprecious electrocatalysts.
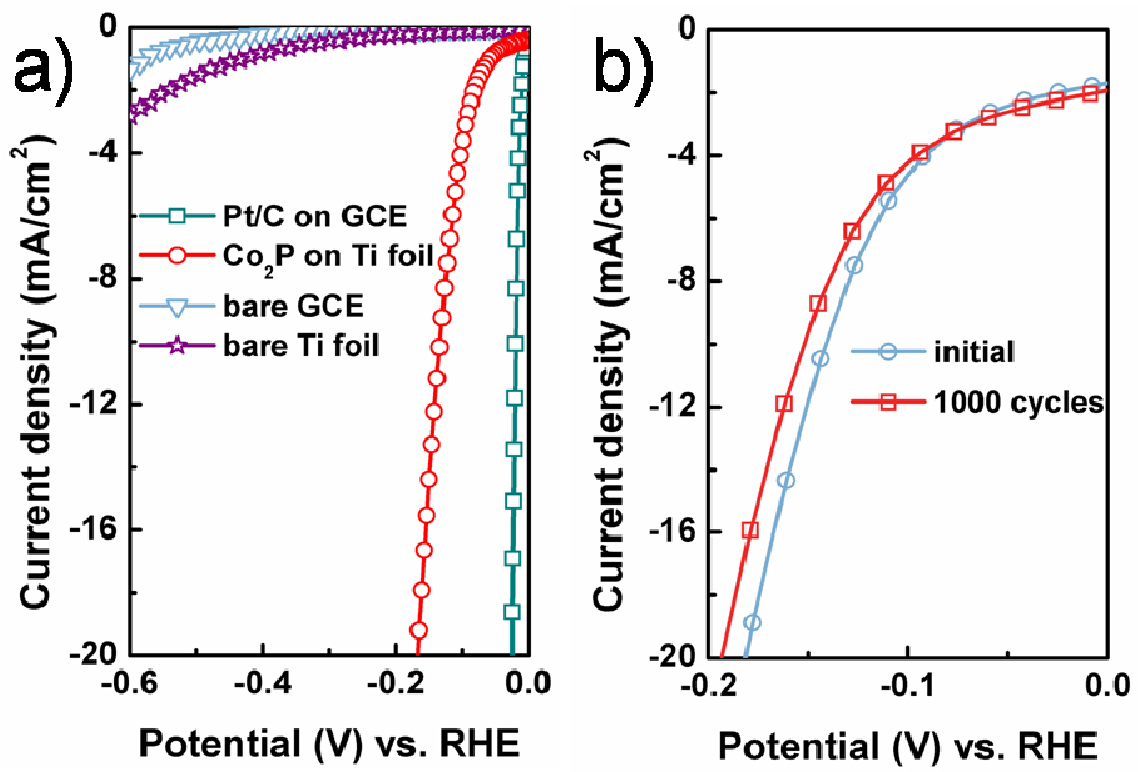

Figure 4. (a) Polarization curves of $\mathrm{Pt} / \mathrm{C}$ on GCE (loading amount: $\sim 0.285 \mathrm{~g} / \mathrm{cm}^{2}$ ), $\mathrm{Co}_{2} \mathrm{P}$ on Ti foil, bare GCE, and bare Ti foil in $0.5 \mathrm{M} \mathrm{H}_{2} \mathrm{SO}_{4}$ solution ( $i R$ corrected). The bare Ti foil was subjected to the same annealing treatment as $\mathrm{Co}_{2} \mathrm{P}$ on Ti foil sample prior to the measurement. (b) Polarization curves of $\mathrm{Co}_{2} \mathrm{P}$ on Ti foil in $0.5 \mathrm{M} \mathrm{H}_{2} \mathrm{SO}_{4}$ at different $\mathrm{CV}$ sweeps (without $i R$ correction). 
Table 1. Summary of the HER performance of representative catalysts.

\begin{tabular}{|c|c|c|c|c|c|c|c|c|}
\hline$\overline{\text { Catalyst }}$ & Substrate & $\begin{array}{c}\text { Mass density } \\
\left(\mathrm{mg} / \mathrm{cm}^{2}\right)\end{array}$ & $\begin{array}{l}\eta_{\text {onset }}^{\mathrm{a}} \\
(\mathrm{mV})\end{array}$ & $\begin{array}{c}\eta_{10} \\
(\mathrm{mV}) \\
\end{array}$ & $\begin{array}{c}\eta_{20} \\
(\mathrm{mV}) \\
\end{array}$ & $\begin{array}{c}\text { Tafel slope } \\
(\mathrm{mV} / \mathrm{dec})\end{array}$ & $\begin{array}{c}\mathrm{J}_{0}^{\mathrm{b}} \\
\left(\mathrm{mA} / \mathrm{cm}^{2}\right) \\
\end{array}$ & Electrolyte \\
\hline $\mathrm{Ni}_{2} \mathrm{P}[17]$ & Ti foil & 1 & & 117 & 130 & $\begin{array}{l}46_{\eta=25-125} \\
81_{\eta=150-200}\end{array}$ & $3.3 \times 10^{-3}$ & $0.50 \mathrm{M} \mathrm{H}_{2} \mathrm{SO}_{4}$ \\
\hline $\mathrm{CoP}[30]$ & Ti foil & 2 & & & 85 & 50 & 0.14 & $0.50 \mathrm{M} \mathrm{H}_{2} \mathrm{SO}_{4}$ \\
\hline $\mathrm{CoP}[20]$ & carbon cloth & 0.92 & 38 & 67 & 100 & 51 & 0.288 & $0.50 \mathrm{M} \mathrm{H}_{2} \mathrm{SO}_{4}$ \\
\hline CoP/CNT[18] & GCE & 0.285 & 40 & 122 & 160 & 54 & 0.13 & $0.50 \mathrm{M} \mathrm{H}_{2} \mathrm{SO}_{4}$ \\
\hline $\mathrm{MoP}[22]$ & GCE & 0.36 & 40 & 125 & 151 & 54 & 0.086 & $0.50 \mathrm{M} \mathrm{H}_{2} \mathrm{SO}_{4}$ \\
\hline $\mathrm{MoP}[21]$ & GCE & 0.86 & 50 & 135 & 167 & 54 & 0.034 & $0.50 \mathrm{M} \mathrm{H}_{2} \mathrm{SO}_{4}$ \\
\hline $\begin{array}{l}\text { Ni-Mo } \\
\text { nanopowder[29] }\end{array}$ & Ti foil & 1 & & & 70 & & & $2 \mathrm{M} \mathrm{NaOH}$ \\
\hline $\begin{array}{l}\text { Ni-Mo } \\
\text { nanopowder[29] }\end{array}$ & Ti foil & 3 & & & 80 & & & $0.5 \mathrm{M} \mathrm{H}_{2} \mathrm{SO}_{4}$ \\
\hline $\begin{array}{l}\text { Ni-Mo } \\
\text { nanopowder[29] }\end{array}$ & Ti foil & 1 & & 79 & 107 & & & $1 \mathrm{M} \mathrm{NaOH}$ \\
\hline Bulk $\mathrm{Mo}_{2} \mathrm{C}[8]$ & $\begin{array}{l}\text { carbon paste } \\
\text { electrode }\end{array}$ & 1.4 & $\geqq 100$ & 208 & 224 & $56_{\eta=100-220}$ & $1.3 \times 10^{-3}$ & $0.50 \mathrm{M} \mathrm{H}_{2} \mathrm{SO}_{4}$ \\
\hline Bulk MoB[8] & $\begin{array}{l}\text { carbon paste } \\
\text { electrode }\end{array}$ & 2.5 & $\geqq 100$ & 212 & 227 & $55_{\eta=140-210}$ & $1.4 \times 10^{-3}$ & $0.50 \mathrm{M} \mathrm{H}_{2} \mathrm{SO}_{4}$ \\
\hline $\mathrm{Mo}_{2} \mathrm{C} / \mathrm{CNT}[9]$ & carbon paper & 2 & 63 & 149 & & 55.2 & $1.4 \times 10^{-2}$ & $0.1 \mathrm{M} \mathrm{HClO}_{4}$ \\
\hline $\mathrm{Fe}-\mathrm{WCN}[13]$ & RRDE & 0.4 & 100 & 220 & & 47.1 & & $\begin{array}{c}\mathrm{H}_{2} \mathrm{SO}_{4}(\mathrm{pH} 1)+ \\
\mathrm{Na}_{2} \mathrm{SO}_{4}(0.5 \\
\mathrm{M}) \\
\end{array}$ \\
\hline $\mathrm{Mo}_{1}$ Soy $[10]$ & carbon paper & 1.4 & & 177 & & 66.4 & $1.3 \times 10^{-2}$ & $0.1 \mathrm{M} \mathrm{HClO}_{4}$ \\
\hline $\mathrm{Mo}_{1}$ Soy-RGO $[10]$ & carbon paper & 0.47 & & 109 & & 62.7 & $3.7 \times 10^{-2}$ & $0.1 \mathrm{M} \mathrm{HClO}_{4}$ \\
\hline $\mathrm{Mo}_{2} \mathrm{C} / \mathrm{C}[10]$ & carbon paper & 2 & & 311 & $>$ & 87.6 & $8.1 \times 10^{-3}$ & $0.1 \mathrm{M} \mathrm{HClO}_{4}$ \\
\hline $\mathrm{Co}_{0.6} \mathrm{Mo}_{1.4} \mathrm{~N}_{2}[31]$ & GCE & 0.243 & & 202 & 267 & & $2.3 \times 10^{-4}$ & $0.1 \mathrm{M} \mathrm{HClO}_{4}$ \\
\hline $\begin{array}{l}\mathrm{MoS}_{3}(33 \%) / \mathrm{MWCNT}- \\
\mathrm{NC}[32]\end{array}$ & $\begin{array}{c}\text { silver } \\
\text { electrode }\end{array}$ & 0.255 & 130 & 206 & 226 & $40_{\eta=135-174}$ & $1.35 \times 10^{-4}$ & $1 \mathrm{M} \mathrm{H}_{2} \mathrm{SO}_{4}$ \\
\hline $\begin{array}{l}\text { Core-shell } \mathrm{MoO}_{3^{-}} \\
\mathrm{MoS}_{2} \text { nanowires[33] }\end{array}$ & FTO & & $150-200$ & 254 & 272 & $50-60_{\eta=200}$ & & $0.5 \mathrm{M} \mathrm{H}_{2} \mathrm{SO}_{4}$ \\
\hline $\begin{array}{l}\text { Defect-rich } \mathrm{MoS}_{2} \\
\text { nanosheets[34] }\end{array}$ & $\mathrm{GCE}$ & 0.285 & 120 & 190 & 214 & $50_{\eta=120-180}$ & $8.91 \times 10^{-3}$ & $0.5 \mathrm{M} \mathrm{H}_{2} \mathrm{SO}_{4}$ \\
\hline $\mathrm{MoS}_{2} @ \mathrm{Au}[35]$ & Au electrode & 0.00103 & 90 & 226 & & 69 & $9.3 \times 10^{-3}$ & $0.5 \mathrm{M} \mathrm{H}_{2} \mathrm{SO}_{4}$ \\
\hline $\begin{array}{l}\text { amorphous } \mathrm{MoS}_{3^{-}} \\
\text {CV[7] }\end{array}$ & $\mathrm{GCE}$ & & & 211 & 229 & $40_{\eta=170-200}$ & $1.3 \times 10^{-4}$ & $1 \mathrm{M} \mathrm{H}_{2} \mathrm{SO}_{4}$ \\
\hline $\mathrm{MoS}_{2} / \mathrm{RGO}$ hybrid[25] & GCE & 0.285 & 100 & 154 & 176 & 41 & & $0.5 \mathrm{M} \mathrm{H}_{2} \mathrm{SO}_{4}$ \\
\hline $\mathrm{MoS}_{2} / \mathrm{MGF}[24]$ & GCE & 0.21 & 100 & 146 & 159 & $42_{\eta=90-120}$ & & $0.5 \mathrm{M} \mathrm{H}_{2} \mathrm{SO}_{4}$ \\
\hline $\mathrm{MoS}_{2} / \mathrm{CNTs}[36]$ & $\begin{array}{c}\text { glass carbon } \\
\text { disk }\end{array}$ & 0.136 & 90 & 184 & 230 & 44.6 & & $0.5 \mathrm{M} \mathrm{H}_{2} \mathrm{SO}_{4}$ \\
\hline $\mathrm{Cu}_{2} \mathrm{MoS}_{4}[37]$ & GCE & 0.0425 & 135 & 321 & & 95 & & $\mathrm{pH} 0 \mathrm{H}_{2} \mathrm{SO}_{4}$ \\
\hline $\mathrm{WS}_{2} / \mathrm{RGO}[38]$ & $\mathrm{GCE}$ & 0.4 & $150-200$ & 265 & 292 & 58 & & $0.5 \mathrm{M} \mathrm{H}_{2} \mathrm{SO}_{4}$ \\
\hline $\mathrm{WS}_{2}$ nanosheets[39] & GCE & $\begin{array}{c}0.0001-0.0002 \\
\text { or ca. one } \\
\text { continuous } \\
\text { layer } \\
\end{array}$ & $80-100$ & 233 & 275 & 55 & & $0.5 \mathrm{M} \mathrm{H}_{2} \mathrm{SO}_{4}$ \\
\hline $\mathrm{WS}_{2}$ nanosheets[40] & GCE & 0.285 & 60 & 151 & 177 & 72 & $2.5 \times 10^{-3}$ & $1 \mathrm{M} \mathrm{H}_{2} \mathrm{SO}_{4}$ \\
\hline $\begin{array}{l}\text { Cobalt-sulfide } \\
\text { catalyst[41] }\end{array}$ & FTO & & 43 & 165 & 227 & 93 & & $\begin{array}{c}1.0 \mathrm{M} \mathrm{pH} 7 \\
\text { PBS }\end{array}$ \\
\hline $\mathrm{NiWS}_{\mathrm{x}}[42]$ & FTO & & 165 & 373 & 430 & $96_{\eta=120-150}$ & $10^{-2.66}$ & pH 7 PBS \\
\hline $\mathrm{CoWS}_{\mathrm{x}}[42]$ & FTO & & 95 & 271 & 311 & $78_{\eta=120-150}$ & $10^{-2.25}$ & pH 7 PBS \\
\hline $\mathrm{CoMoS}_{\mathrm{x}}[42]$ & FTO & & 75 & 241 & 282 & $85_{\eta=120-150}$ & $10^{-2.89}$ & pH 7 PBS \\
\hline $\mathrm{FeS}_{2}[15]$ & GCE & & & 192.6 & & 62.5 & $7 \times 10^{-4}$ & $0.5 \mathrm{M} \mathrm{H}_{2} \mathrm{SO}_{4}$ \\
\hline $\mathrm{FeSe}_{2}[15]$ & GCE & & & & & 65.3 & $3.5 \times 10^{-4}$ & $0.5 \mathrm{M} \mathrm{H}_{2} \mathrm{SO}_{4}$ \\
\hline $\mathrm{Fe}_{0.43} \mathrm{Co}_{0.57} \mathrm{~S}_{2}[15]$ & GCE & & & 264 & & 55.9 & $1.3 \times 10^{-3}$ & $0.5 \mathrm{M} \mathrm{H}_{2} \mathrm{SO}_{4}$ \\
\hline $\mathrm{CoS}_{2}[15]$ & GCE & & & 232 & & 44.6 & $6.5 \times 10^{-5}$ & $0.5 \mathrm{M} \mathrm{H}_{2} \mathrm{SO}_{4}$ \\
\hline $\mathrm{CoSe}_{2}[15]$ & GCE & 0.037 & 45 & 231 & & 42.4 & $6.5 \times 10^{-5}$ & $0.5 \mathrm{M} \mathrm{H}_{2} \mathrm{SO}_{4}$ \\
\hline $\mathrm{Co}_{0.56} \mathrm{Ni}_{0.44} \mathrm{Se}_{2}[15]$ & GCE & & & 250 & & 49.7 & $6.3 \times 10^{-5}$ & $0.5 \mathrm{M} \mathrm{H}_{2} \mathrm{SO}_{4}$ \\
\hline $\mathrm{Co}_{0.32} \mathrm{Ni}_{0.68} \mathrm{~S}_{2}[15]$ & GCE & & & & & 66.8 & $3.0 \times 10^{-4}$ & $0.5 \mathrm{M} \mathrm{H}_{2} \mathrm{SO}_{4}$ \\
\hline $\mathrm{NiS}_{2}[15]$ & GCE & & & & & 41.6 & $1.4 \times 10^{-4}$ & $0.5 \mathrm{M} \mathrm{H}_{2} \mathrm{SO}_{4}$ \\
\hline
\end{tabular}




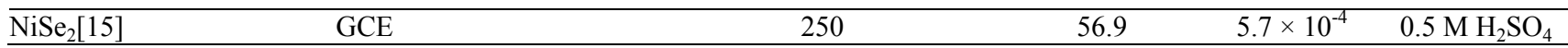

${ }^{a} \eta_{\text {onset: }}$ overpotential for the onset of reductive current

${ }^{\mathrm{b}} \mathrm{J}_{0}$ : exchange current density

High durability is of importance for a good electrocatalyst. The stability of the $\mathrm{Co}_{2} \mathrm{P}$ nanorods was evaluated by cyclic voltammetry (CV) sweeps between -0.240 and $0.100 \mathrm{~V}$ vs. RHE in the $0.5 \mathrm{M}$ $\mathrm{H}_{2} \mathrm{SO}_{4}$ solution. The corresponding $j-V$ curves of the $\mathrm{CV}$ sweeps (without $i R$ correction) are shown in Figure $4 \mathrm{~b}$. After $1000 \mathrm{CV}$ sweeps the $\eta_{20}$ increases from $181 \mathrm{mV}$ to $194 \mathrm{mV}$, the increase of the $\eta_{20}$ being smaller than $15 \mathrm{mV}$. The current density at $0 \mathrm{~V}$ vs. RHE in CV sweeps $\left(2 \mathrm{~mA} / \mathrm{cm}^{2}\right.$, Figure $\left.4 \mathrm{~b}\right)$ is larger than that in Figure $4 \mathrm{a}\left(\sim 0 \mathrm{~mA} / \mathrm{cm}^{2}\right)$. It is apparent that the larger current density is correlated with the faster scan rate $(50 \mathrm{mV} / \mathrm{s})$ in $\mathrm{CV}$ sweeps, implying that the current density at $0 \mathrm{~V}$ vs. RHE in CV sweeps could be associated with the capacitive process on the surface of the catalyst. In addition, current density exhibits only ca. $10 \%$ decrease after $12 \mathrm{~h}$ potentiostatic electrolysis (Figure S7, Electronic Supplementary Information). The CV sweeps and potentiostatic electrolysis experiment suggest the HER stability of the $\mathrm{Co}_{2} \mathrm{P}$ nanorods in acidic solution.

Thus far, only rare excellent catalysts (e.g. Pt and $\mathrm{Mo}_{2} \mathrm{C}$ )[8] have been shown to perform reliably in both acidic and basic solution. For this reason, the HER performance of the $\mathrm{Co}_{2} \mathrm{P}$ nanorods in basic solution $(\mathrm{KOH}, 1 \mathrm{M})$ was also evaluated. The corresponding results are shown in Figure S8 (Electronic Supplementary Information), with a $\eta_{20}$ value of $171 \mathrm{mV}$ (iR corrected). After $1000 \mathrm{CV}$ sweeps between -0.330 and $0.080 \mathrm{~V}$ vs. RHE, the $\eta_{20}$ increases from $217 \mathrm{mV}$ to $229 \mathrm{mV}$ (without $i R$ correction). The relatively small increase of the $\eta_{20}(12 \mathrm{mV})$ and a potentiostatic electrolysis 
experiment (Figure S8c, Electronic Supplementary Information) shows the stability of the $\mathrm{Co}_{2} \mathrm{P}$ nanorods in the basic solution. These experiments demonstrate that the $\mathrm{Co}_{2} \mathrm{P}$ nanorods can function efficiently and stably under the basic condition as well. It has been reported that the $\eta_{20}$ of $\mathrm{Ni}_{2} \mathrm{P}$ nanoparticles in basic solution (KOH, $1 \mathrm{M}$ ) is $205 \mathrm{mV}$, and the HER performance declined rapidly on cycling.[17] The reason for the different stabilities of the $\mathrm{Co}_{2} \mathrm{P}$ nanorods and the $\mathrm{Ni}_{2} \mathrm{P}$ nanoparticles in basic solution remains unknown, but the different crystal structures (orthorhombic $\mathrm{Co}_{2} \mathrm{P}$ and hexagonal $\left.\mathrm{Ni}_{2} \mathrm{P}\right)$ are likely to be an important factor.

The faradaic efficiency of the $\mathrm{Co}_{2} \mathrm{P}$ nanorods during $\mathrm{H}_{2}$ evolution was probed by comparing the volume of generated gas and quantity of charges passing the $\mathrm{Co}_{2} \mathrm{P}$ nanorods while a potentiostatic electrolysis measurement was carried out. The volume of generated gas was monitored by the water displacement method. Figure 5 shows the comparison of the theoretical volume of hydrogen and the experimentally measured volume of hydrogen. $10 \mathrm{C}$ of charge pass through the cathode $\left(\sim 0.5 \mathrm{~cm}^{2}\right)$ in $1310 \mathrm{~s}, 1.25 \mathrm{~mL}$ of $\mathrm{H}_{2}$ should be produced according to the theoretical computation. In the experiment, the volume of generated $\mathrm{H}_{2}$ was measured to be $1.18 \mathrm{~mL}$, very close to the theoretical value. In addition, the faradaic yield of $\mathrm{H}_{2}$ production is nearly $100 \%$ over the time scale of the measurement (Figure 5). 


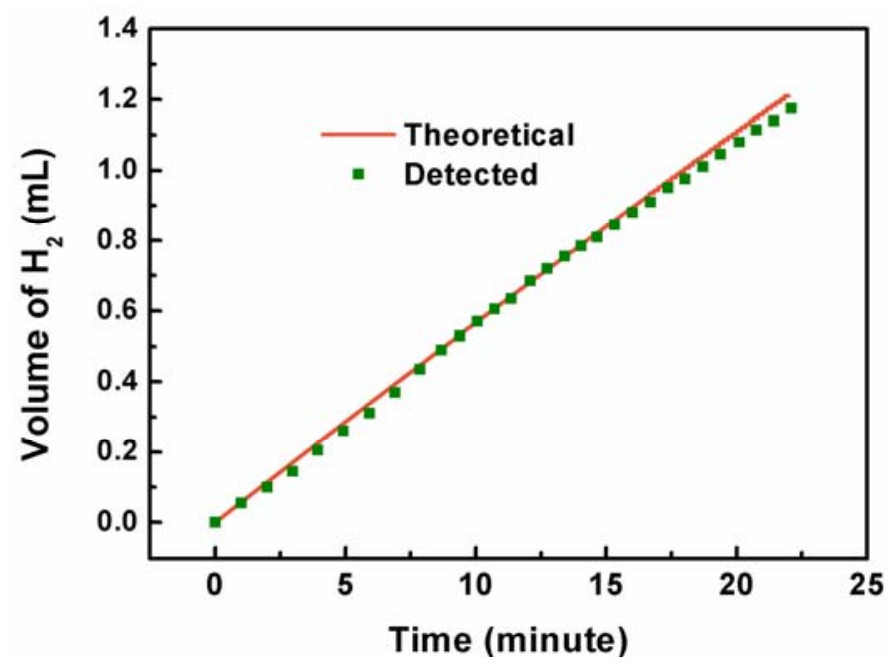

Figure 5. Current efficiency for HER under potentiostatic electrolysis (applied potential: $-150 \mathrm{mV}$ vs. RHE).

To obtain insight into the HER process and mechanism with the $\mathrm{Co}_{2} \mathrm{P}$ nanorods, electrochemical impedance spectroscopy (EIS) investigations were carried out. The EIS experiments were carried out at different applied potentials, the results being shown in Nyquist plots in Figure 6. The EIS spectra display two semicircles. The semicircles at high frequencies (shown more clearly in Figure $6 \mathrm{~b}$ ) can be related to the contact between the catalyst $\left(\mathrm{Co}_{2} \mathrm{P}\right)$ and the catalyst support (Ti foil), while those at low frequencies correspond to the kinetics of the HER process on the surface of the catalyst.

The diameters of the semicircles at low frequencies are potential-dependent, decreasing with increasing applied potential. This is qualitatively in accordance with faster HER kinetics occurring at higher overpotential. The kinetics of electrochemical reaction at an electrode's surface is usually assessed by charge transfer resistance $\left(R_{c t}\right)$, with a smaller $R_{c t}$ value corresponding to faster kinetics. $\mathrm{R}_{\mathrm{ct}}$ can be deduced from EIS spectra by data fitting, in the present case using the equivalent circuit shown in Figure S9 (Electronic Supplementary Information). The results are listed in Table S1 
(Electronic Supplementary Information). The high frequency constant phase element $\left(\mathrm{CPE}_{1}\right)$ and resistance element $\left(\mathrm{R}_{1}\right)$ are nearly potential-independent (Figures $\mathrm{S} 10 \mathrm{a}$ and $\mathrm{S} 10 \mathrm{~b}$, Electronic Supplementary Information). In contrast, $\mathrm{R}_{\mathrm{ct}}$ is potential-dependent (Figure $\mathrm{S} 10 \mathrm{~d}$, Electronic Supplementary Information) whereas the low frequency constant phase element $\left(\mathrm{CPE}_{\mathrm{dl}}\right)$ is nearly potential-independent (Figure S10c, Electronic Supplementary Information). The invariant $\mathrm{CPE}_{\mathrm{dl}}$ value suggests that the active surface area of the catalyst is maintained at different applied potentials, consistent with a high durability of the catalyst.
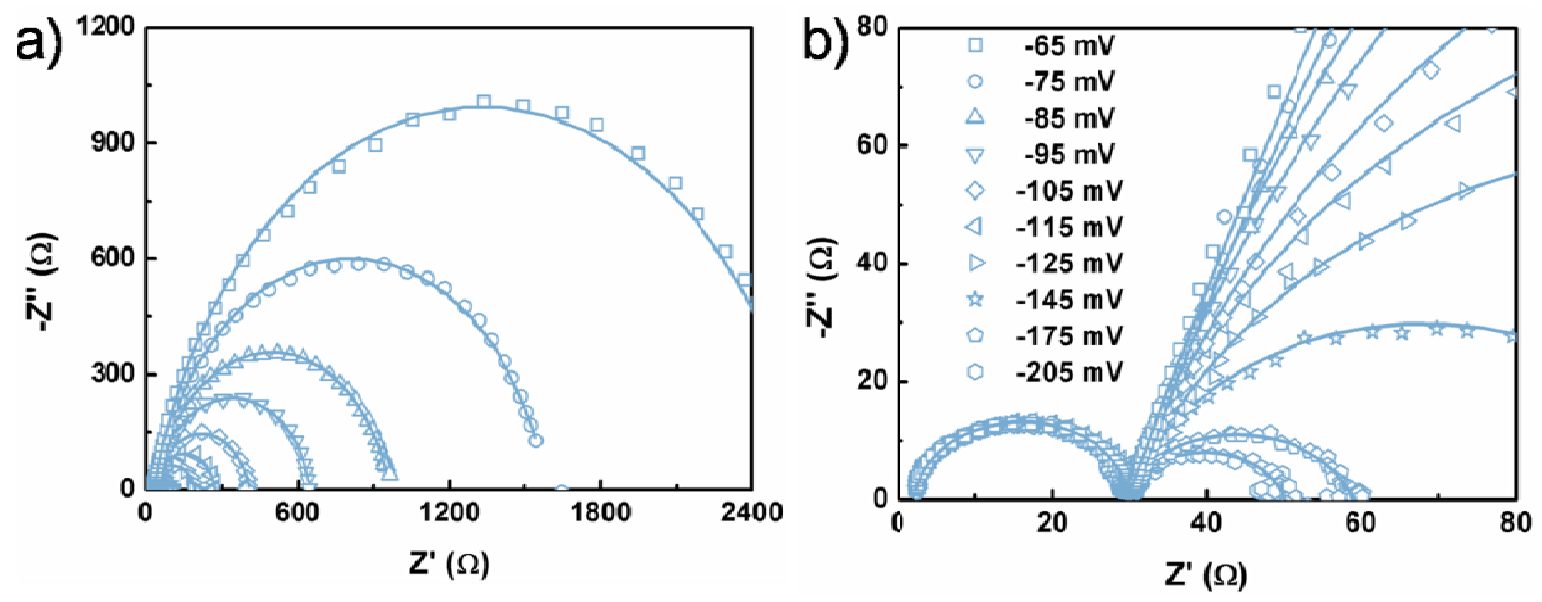

Figure 6. Nyquist plots of EIS responses of the $\mathrm{Co}_{2} \mathrm{P}$ nanorods at different applied potentials in $0.5 \mathrm{M}$ $\mathrm{H}_{2} \mathrm{SO}_{4}$ solution: (a) the overall spectra, and (b) data near the high frequency region. The scatters show the experimental data, and lines show the results of fitting to the equivalent circuit in Figure S9.

In general, classic two-electron-reaction models suggest that the HER process proceeds in two steps: a discharge step (Volmer reaction: $\mathrm{H}_{3} \mathrm{O}^{+}+\mathrm{e}^{-} \rightarrow \mathrm{H}_{\text {ads }}+\mathrm{H}_{2} \mathrm{O}$ ) followed by a desorption step (Heyrovsky reaction: $\mathrm{H}_{\text {ads }}+\mathrm{H}_{3} \mathrm{O}^{+}+\mathrm{e}^{-} \rightarrow \mathrm{H}_{2}+\mathrm{H}_{2} \mathrm{O}$ ), or a discharge step followed by a recombination step (Tafel reaction: $\mathrm{H}_{\mathrm{ads}}+\mathrm{H}_{\mathrm{ads}} \rightarrow \mathrm{H}_{2}$ ), where $\mathrm{H}_{\text {ads }}$ represents an $\mathrm{H}$ atom absorbed at the active site of the catalyst. The rate-limiting step can be identified by the Tafel analysis of the catalyst, with a Tafel 
slope of 116,38 , or $29 \mathrm{mV} /$ decade assigning the rate-determining step in the HER process to Volmer, Heyrovsky, or Tafel reaction. The polarization curve (Figure 4a) is presented in a Tafel plot in Figure 7a, and the apparent Tafel slope obtained by fitting the linear portion of the Tafel plot to the Tafel equation. The apparent Tafel slope of $\mathrm{Co}_{2} \mathrm{P}$ fitted from the polarization curve is $71.0 \mathrm{mV} / \mathrm{decade}$. The apparent Tafel slope extracted from the polarization curve will be higher than the true value, if electron transport in the catalyst is sufficiently slow. For example, it has been shown that different loading amounts of $\mathrm{MoS}_{\mathrm{x}}$ on GCE result in different Tafel slopes,[43] and the introduction of reduced graphene oxide to $\mathrm{MoS}_{2}$ can markedly reduce the Tafel slope.[25] Hu and Vrubel et al. demonstrated that the contribution of the electron transport process in the catalyst to the Tafel slope can be eliminated if the Tafel slope is derived from EIS data.[43] The $\log \left(1 / \mathrm{R}_{\mathrm{ct}}\right)-\eta$ plot of the $\mathrm{Co}_{2} \mathrm{P}$ nanorods is shown in Figure 7b, showing a Tafel slope of $51.7 \mathrm{mV} /$ decade.

The Tafel slope of $51.7 \mathrm{mV} /$ decade lies between 38 and $116 \mathrm{mV} /$ decade, suggesting that a Volmer-Heyrovsky mechanism might be responsible for the HER process,[10] and that the rates of the discharge step and the desorption step might be comparable during the HER process.[16] The Tafel slope fitted from the polarization curve is larger than that obtained from $\mathrm{R}_{\mathrm{ct}}$, suggesting that electron transport resistance in the catalyst may be well comparable to the charge transfer resistance at the catalyst/electrolyte interface. The apparent Tafel slope would thereby be reduced and, accordingly, the HER performance could be further improved by reducing the electron transport resistance in the catalyst, for example via the introduction of conductive graphene.[25] On the other hand, the turnover 
frequencies (TOFs) of the HER were estimated according to the number active sites determined by CV sweep. [7] In this approach the total number of active sites is the upper limit value. Figure S11 (Electronic Supplementary Information) shows the plot of TOFs versus the applied potentials in the $0.5 \mathrm{M} \mathrm{H}_{2} \mathrm{SO}_{4}$ solution. The $\mathrm{Co}_{2} \mathrm{P}$ nanorods show a TOF of $0.725 \mathrm{~S}^{-1}$ at $-143 \mathrm{mV}$ vs. RHE. This value is larger than that of $\mathrm{CoP} / \mathrm{CC}\left(\sim-75 \mathrm{mV}\right.$ vs. RHE),[20] and smaller than that of $\mathrm{MoS}_{3}$ deposited on GCE ( -220 mV vs. RHE). [7]
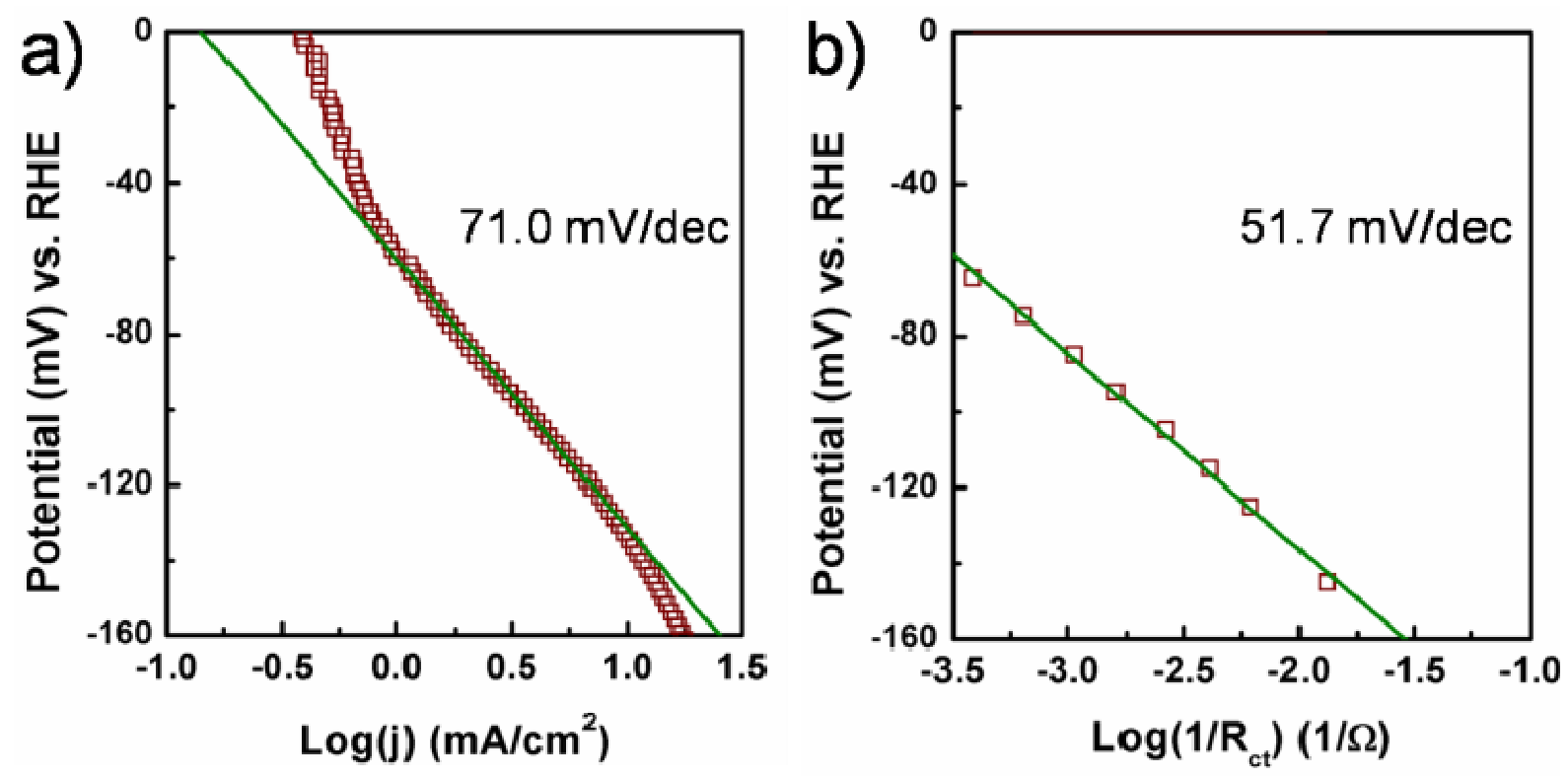

Figure 7. (a) Apparent Tafel slope fitted from polarization data measured in $0.5 \mathrm{M} \mathrm{H}_{2} \mathrm{SO}_{4}$ solution, and (b) Tafel slope fitted from EIS data measured in $0.5 \mathrm{M} \mathrm{H}_{2} \mathrm{SO}_{4}$ solution. Scatters show experimental data and the solid lines show the corresponding fitting.

The HER catalytic activity of the $\mathrm{Co}_{2} \mathrm{P}$ nanorods might be correlated with the unique charged natures of $\mathrm{Co}$ and $\mathrm{P}$ species. The kinetics of HER in $[\mathrm{NiFe}]$ hydrogenase and its analogues $\left(\left[\mathrm{Ni}\left(\mathrm{PS}^{*}\right)(\mathrm{CO})\right]^{1-}\right.$ and $\left.\left[\mathrm{Ni}(\mathrm{PNP})_{2}\right]^{2+}\right)$ have been assessed via density functional theory simulation.[23] It was revealed that the efficient hydrogenase and its analogues have both proton acceptor and hydride 
acceptor sites. The proton acceptor site is the nonmetal site having a small negative charge to trap protons (e.g., $\mathrm{O}$ of Glu23 in hydrogenase, $-0.44 \mathrm{e} ; \mathrm{S}$ in $\left.\mathrm{Ni}\left(\mathrm{PS}^{*}\right)(\mathrm{CO})\right]^{1-},-0.4 \mathrm{e} ; \mathrm{N}$ in $\left[\mathrm{Ni}(\mathrm{PNP})_{2}\right]^{2+},-$ 0.34 e). The hydride acceptor site ( $\mathrm{Ni}$ in hydrogenase, $\mathrm{Ni}(\mathrm{PS} 3 *)(\mathrm{CO})]^{1-}$, and $\left[\mathrm{Ni}(\mathrm{PNP})_{2}\right]^{2+}$ ) is the isolated metal atom providing moderate bonding to hydrogen, and the hydride acceptor site has a slightly positive charge, suggested by the calculated total electron density of hydrogenase, $\left.\mathrm{Ni}\left(\mathrm{PS}^{*}\right)(\mathrm{CO})\right]^{1-}$, and $\left[\mathrm{Ni}(\mathrm{PNP})_{2}\right]^{2+}$. The proton acceptor and hydride acceptor sites work cooperatively, resulting in high HER catalytic activities. $\mathrm{Ni}_{2} \mathrm{P}(001)$ also has proton acceptor sites $(\mathrm{P})$ and hydride acceptor sites (Ni), and it has been predicted[23] and then proved[17] to be highly active HER catalyst. The hydride acceptor (Ni) and proton acceptor $(\mathrm{P})$ in $\mathrm{Ni}_{2} \mathrm{P}$ has small positive and negative charges, respectively, suggested by the fact that the peak binding energies of $\mathrm{Ni}(853.5 \mathrm{eV})$ and $\mathrm{P}(129.5 \mathrm{eV})$ in $\mathrm{Ni}_{2} \mathrm{P}$ are very close to those of the corresponding zero valence species $(852.8 \mathrm{eV}$ for $\mathrm{Ni}$ and $130.0 \mathrm{eV}$ for P).[44] It has been revealed that $\mathrm{Co}$ and $\mathrm{P}$ in $\mathrm{Co}_{2} \mathrm{P}$ also have a small positive and negative charge (Figure 3 and corresponding discussion). The charged natures of $\mathrm{Co}$ and $\mathrm{P}$ in $\mathrm{Co}_{2} \mathrm{P}$ are therefore similar to those of hydride acceptor and proton acceptor in $\mathrm{Ni}_{2} \mathrm{P}$, [NiFe] hydrogenase, $\left[\mathrm{Ni}\left(\mathrm{PS}^{*}\right)(\mathrm{CO})\right]^{1-}$, and $\left.\left[\mathrm{Ni}(\mathrm{PNP})_{2}\right]^{2+}\right)$, respectively. The similarity in charged natures implies that similar catalytic mechanism might work in the $\mathrm{Co}_{2} \mathrm{P}$ nanorods as $\mathrm{Ni}_{2} \mathrm{P}$, [NiFe] hydrogenase, $[\mathrm{Ni}(\mathrm{PS} 3 *)(\mathrm{CO})]^{1-}$, and $\left.\left[\mathrm{Ni}(\mathrm{PNP})_{2}\right]^{2+}\right)$, resulting to high HER catalytic activity reported here. 


\section{Conclusions}

In conclusion, $\mathrm{Co}_{2} \mathrm{P}$ nanorods were demonstrated as a new efficient HER electrocatalyst. The HER performance of the $\mathrm{Co}_{2} \mathrm{P}$ nanorods is comparable to those of high efficiently non-precious electrocatalysts. Accelerated degradation and potentiostatic electrolysis experiments have demonstrated the stability of the $\mathrm{Co}_{2} \mathrm{P}$ nanorods in acidic and basic solution during the HER process. The faradaic yield of $\mathrm{H}_{2}$ production is nearly $100 \%$. The HER process was found to follow a VolmerHeyrovsky mechanism, and the rates of the discharge and desorption step appear to be comparable during the HER process. The HER performance could be further improved by the introduction of conductive species. Studies directed toward this goal are currently underway.

\section{Acknowledgements}

This research was financially supported by the National Natural Science Foundation of China (61006049, 50925207), the Ministry of Science and Technology of China (2011DFG52970), the Ministry of Education of China (IRT1064), 111 Project (B13025), Jiangsu Innovation Research Team, Jiangsu Province (2011-XCL-019 and 2013-479), Natural Science Foundation of Jiangsu. M.G.H. thanks the Australian Research Council for support. 


\section{References}

[1] S. S. Mao, X. B. Chen, Inter. J. Energ. Res., 31 (2007) 619-636.

[2] T. R. Cook, D. K. Dogutan, S. Y. Reece, Y. Surendranath, T. S. Teets, D. G. Nocera, Chem.

Rev., 110 (2010) 6474-6502.

[3] M. G. Walter, E. L. Warren, J. R. McKone, S. W. Boettcher, Q. X. Mi, E. A. Santori, N. S.

Lewis, Chem. Rev., 110 (2010) 6446-6473.

[4] M. Szklarczyk, J. O. M. Bockris, Appl. Phys. Lett., 42 (1983) 1035-1036.

[5] R. N. Dominey, N. S. Lewis, J. A. Bruce, D. C. Bookbinder, M. S. Wrighton, J Am Chem Soc, 104 (1982) 467-482.

[6] B. Hinnemann, P. G. Moses, J. Bonde, K. P. Jørgensen, J. H. Nielsen, S. Horch, I.

Chorkendorff, J. K. Nørskov, J Am Chem Soc, 127 (2005) 5308-5309.

[7] D. Merki, S. Fierro, H. Vrubel, X. L. Hu, Chem. Sci., 2 (2011) 1262-1267.

[8] H. Vrubel, X. L. Hu, Angew. Chem. Int. Ed., 51 (2012) 12703-12706.

[9] W. F. Chen, C. H. Wang, K. Sasaki, N. Marinkovic, W. Xu, J. T. Muckerman, Y. Zhu, R. R. Adzic, Energ. Environ. Sci., 6 (2013) 943-951.

[10] W. F. Chen, S. Iyer, S. Iyer, K. Sasaki, C. H. Wang, Y. M. Zhu, J. T. Muckerman, E. Fujita, Energ. Environ. Sci., 6 (2013) 1818-1826. 
[11] F. Harnisch, G. Sievers, U. Schröder, Appl. Catal. B- Environ., 89 (2009) 455-458.

[12] S. Wirth, F. Harnisch, M. Weinmann, U. Schröder, Appl. Catal. B- Environ., 126 (2012) 225230.

[13] Y. Zhao, K. Kamiya, K. Hashimoto, S. Nakanishi, Angew. Chem. Int. Ed., 52 (2013) 1-5.

[14] A. Ivanovskaya, N. Singh, R. F. Liu, H. Kreutzer, J. Baltrusaitis, T. V. Nguyen, H. Metiu, E. McFarland, Langmuir, 29 (2013) 480-492.

[15] D. S. Kong, J. J. Cha, H. T. Wang, H. R. Lee, Y. Cui, Energ. Environ. Sci., 6 (2013) 35533558.

[16] M. R. Gao, Z. Y. Lin, T. T. Zhuang, J. Jiang, Y. F. Xu, Y. R. Zheng, S. H. Yu, J. Mater. Chem., $22(2012)$ 13662-13668.

[17] E. J. Popczun, J. R. McKone, C. G. Read, A. J. Biacchi, A. M. Wiltrout, N. S. Lewis, R. E. Schaak, J Am Chem Soc, 135 (2013) 9267-9270.

[18] Q. Liu, J. Q. Tian, W. Cui, P. Jiang, N. Y. Cheng, A. M. Asiri, X. P. Sun, Angew. Chem. Inter. Ed., 53 (2014) 6710-6714.

[19] E. J. Popczun, C. G. Read, C. W. Roske, N. S. Lewis, R. E. Schaak, Angew. Chem. Inter. Ed., 53 (2014) 5427-5430.

[20] J. Q. Tian, Q. Liu, A. M. Asiri, X. P. Sun, J Am Chem Soc, 136 (2014) 7587-7590.

[21] P. Xiao, M. A. Sk, L. Thia, X. M. Ge, R. J. Lim, J. Y. Wang, K. H. Lim, X. Wang, Energy Environ. Sci., 7 (2014). 
[22] Z. C. Xing, Q. Liu, A. M. Asiri, X. P. Sun, Adv. Mater., DOI:10.1002/adma.201401692 (2014).

[23] P. Liu, J. A. Rodriguez, J Am Chem Soc, 127 (2005) 14871-14878.

[24] L. Liao, J. Zhu, X. J. Bian, L. N. Zhu, M. D. Scanlon, H. H. Girault, B. H. Liu, Adv. Funct. Mater., 23 (2013) 5326-5333.

[25] Y. Li, H. Wang, L. Xie, Y. Liang, G. Hong, H. Dai, J Am Chem Soc, 133 (2011) 7296-7299.

[26] V. V. Nemoshalenko, V. V. Didyk, V. P. Krivitskii, A. I. Senekevich, Zh. Neorg. Khimii, 28 (1983) 2182-2192.

[27] V. I. Nefedov, Y. V. Salyn, E. P. Domashevskaya, Y. A. Ugai, V. A. Terekhov, J. Electron Spectrosc. Relat. Phenom., 6 (1975) 231-238.

[28] S. Cobo, J. Heidkamp, P. Jacques, J. Fize, V. Fourmond, L. Guetaz, B. Jousselme, V. Ivanova, H. Dau, S. Palacin, M. Fontecave, V. Artero, Nat. Mater., 11 (2012) 802-807.

[29] J. R. McKone, B. F. Sadtler, C. A. Werlang, N. S. Lewis, H. B. Gray, ACS Catal., 3 (2013) 166-169.

[30] E. J. Popczun, C. G. Read, C. W. Roske, N. S. Lewis, R. E. Schaak, Angew. Chem. Inter. Ed., 53 (2014) 5427-5430.

[31] B. F. Cao, C. M. Veith, J. C. Neuefeind, R. R. Adzic, P. G. Khalifah, J Am Chem Soc, 135 (2013) 19186-19192.

[32] T. W. Lin, C. J. Liu, J. Y. Lin, Appl. Catal. B- Environ., 134-135 (2013) 75-82. 
[33] Z. Chen, D. Cummins, B. N. Reinecke, E. Clark, M. K. Sunkara, T. F. Jaramillo, Nano. Lett., $11(2011) 4168-4175$.

[34] J. Xie, H. Zhang, S. Li, R. Wang, X. Sun, M. Zhou, J. Zhou, X. W. Lou, Y. Xie, Adv. Mater., 25 (2013) 5807-5813.

[35] T. Y. Wang, L. Liu, Z. W. Zhu, P. Papakonstantinou, J. B. Hu, M. Li, Energy Environ. Sci., 6 (2013) 625-633.

[36] Y. Yan, X. Ge, Z. Liu, J. Y. Wang, J. M. Lee, X. Wang, Nanoscale, 5 (2013) 7768-7771.

[37] P. D. Tran, M. Nguyen, S. S. Pramana, A. Bhattacharjee, S. Y. Chiam, J. Fize, M. J. Field, V. Artero, L. H. Wong, J. Loo, J. Barber, Energ. Environ. Sci., 5 (2012) 8912-8916.

[38] J. Yang, D. Voiry, S. J. Ahn, D. Kang, A. Y. Kim, M. Chhowalla, H. S. Shin, Angew. Chem. Int. Ed., 52 (2013) 13751-13754.

[39] D. Voiry, H. Yamaguchi, J. Li, R. Silva, D. C. Alves, T. Fujita, M. Chen, T. Asefa, V. B. Shenoy, G. Eda, M. Chhowalla, Nat. Mater., 12 (2013) 850-855.

[40] Z. Z. Wu, B. Z. Fang, B. Arman, A. K. Sun, D. P. Wilkinson, D. Z. Wang, Appl. Catal. BEnviron., 125 (2012) 59-66.

[41] Y. Sun, C. Liu, D. C. Grauer, J. Yano, J. R. Long, P. Yang, C. J. Chang, J Am Chem Soc, 135 (2013) 17699-17702.

[42] P. D. Tran, S. Y. Chiam, P. P. Boix, Y. Ren, S. S. Pramana, J. Fize, V. Artero, J. Barber, Energ.

Environ. Sci., 6 (2013) 2452-2459. 
[43] H. Vrubel, T. Moehl, M. Gratzel, X. L. Hu, Chem. Commun. , 49 (2013) 8985-8987.

[44] S. J. Sawhill, K. A. Layman, D. R. Van Wyk, M. H. Engelhard, C. Wang, M. E. Bussell, J. Catal., 231 (2005) 300-313. 


\section{Research highlight}

A convenient method is used to fabricate cobalt phosphide $\left(\mathrm{Co}_{2} \mathrm{P}\right)$ nanorods.

$\mathrm{Co}_{2} \mathrm{P}$ nanorods exhibit efficient electrocatalytic activity in hydrogen evolution reaction.

$\mathrm{Co}_{2} \mathrm{P}$ nanorods work stably in both acidic and basic solutions. 
Graphical abstract
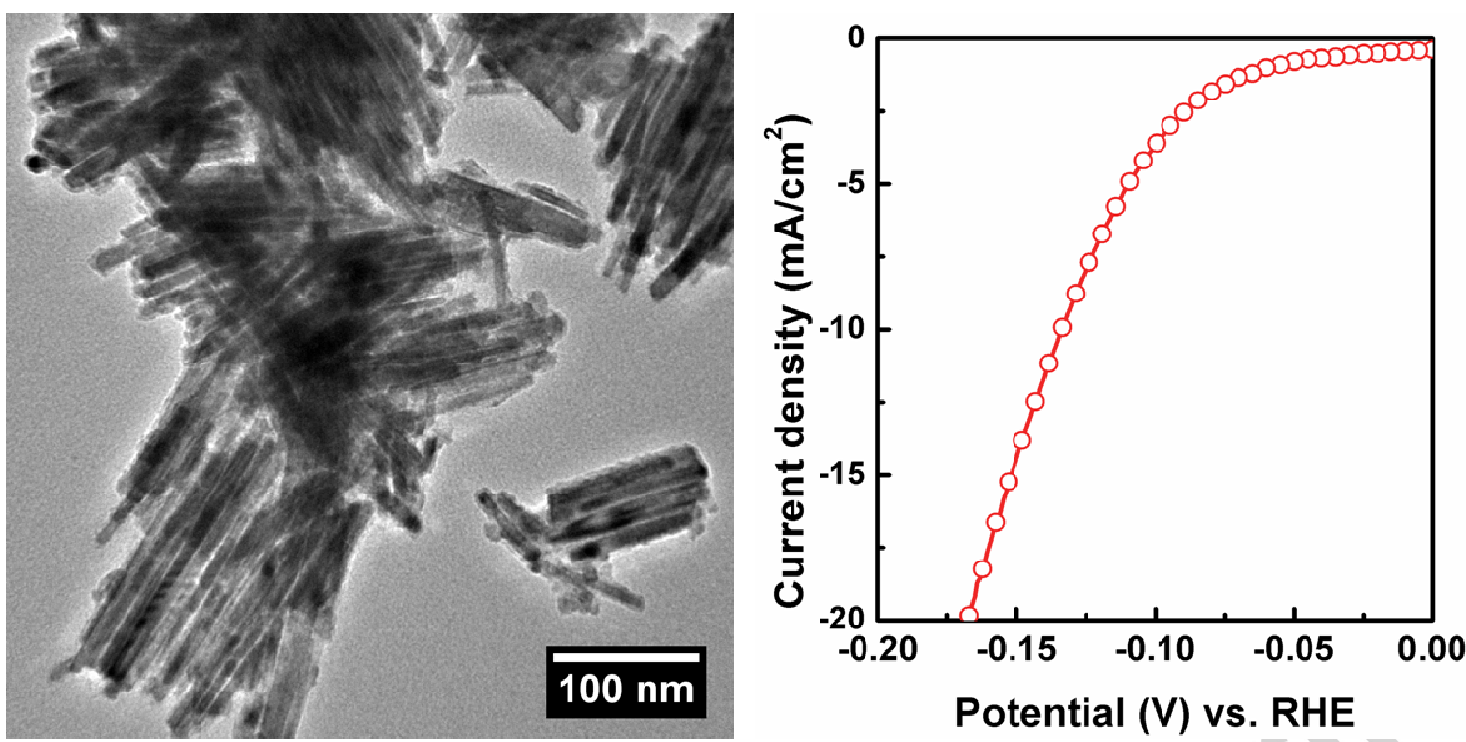